\title{
Keragaman Genetik berbagai Isolat Beauveria bassiana (Bals.) Vuill. (Deuteromycotina: Hyphomycetes) dan Virulensinya terhadap Crocidolomia pavonana
}

\author{
Trizelia $^{1^{*)}}$, Teguh Santoso ${ }^{2)}$, Soemartono Sosromarsono ${ }^{2)}$, Aunu Rauf ${ }^{2)}$, dan Lisdar I Sudirman ${ }^{3)}$ \\ ${ }^{1)}$ Jurusan Hama dan Penyakit Tumbuhan, Fakultas Pertanian, Universitas Andalas, Padang 25163 \\ ${ }^{2}$ Departemen Proteksi Tanaman, Institut Pertanian Bogor, Bogor 16680 \\ 3)Jurusan Biologi, Fakultas Matematika dan Ilmu Pengetahuan Alam, Institut Pertanian Bogor, Bogor 16680
}

Diterima 24-10-2009 Disetujui 17-04-2012

\begin{abstract}
The objectives of the research were to study the genetic variability of various Beauveria bassiana (Bals.) Vuill. isolates and virulence to Crocidolomia pavonana. Thirteen isolates of B. bassiana were isolated from Nilaparvata lugens (Stål), Leptocorisa oratorius (F.), Thrips sp., Hypothenemus hampei (Ferr.), Crocidolomia pavonana (F.), Spodoptera litura (F.), Chrysodeixis chalcites (Esp.), and Riptortus linearis (L.) pests from different geographical locations in Indonesia. Fourteen different random primers were used to amplify DNA. Clustering of isolates were obtained using Unweight Pair Group Method Avarage (UPGMA). The results showed that only OPA08 primer generated more polymorphic DNA fragments. Result of clustering analysis showed that B. bassiana isolates forms two groups having genetic similarity equal to $55 \%$. Clustering of isolates does not correlate to host type nor geographic origin. Mortality of second instar C. pavonana larvae was dependent on the fungal isolates. At a concentration of $10^{8}$ conidia/ml, isolate $\mathrm{Bb}-\mathrm{La} 2 \mathrm{had}$ the highest virulence which caused $65 \%$ mortality of $2^{\text {nd }}$ instar larvae. Isolates of B. bassiana is virulent against $C$. pavonana larvae present in the same genotype group.
\end{abstract}

Keywords: B. bassiana, Crocidolomia pavonana, diversity, genetic, RAPD, virulence

\begin{abstract}
ABSTRAK
Penelitian ini bertujuan untuk mengetahui keragaman genetik berbagai isolat Beauveria bassiana (Bals.) Vuill. dan virulensinya terhadap Crocidolomia pavonana. Tiga belas isolat B. bassiana diisolasi dari hama Nilaparvata lugens (Stal), Leptocorisa oratorius (F.), Thrips sp., Hypothenemus hampei (Ferr.), Crocidolomia pavonana F., Spodoptera litura (F.), Chrysodeixis chalcites (Esp.), dan Riptortus linearis (L.) dari berbagai daerah geografi di Indonesia. Empat belas primer acak digunakan untuk mengamplifikasi DNA. Analisis pengelompokan isolat dilakukan dengan menggunakan metode Unweight Pair Group Method Average (UPGMA). Hasil penelitian menunjukkan bahwa hanya primer OPA08 yang menghasilkan pola pita DNA polimorfik yang lebih banyak. Hasil analisis pengelompokan menunjukkan bahwa isolat B. bassiana membentuk 2 kelompok yang mempunyai kesamaan genetik sebesar 55\%. Pengelompokan isolat tidak berhubungan dengan sumber inang dan geografi isolat. Mortalitas larva $C$. pavonana instar II sangat dipengaruhi oleh jenis isolat. Pada konsentrasi $10^{8} \mathrm{konidia} / \mathrm{mL}$, isolat Bb-La2 memiliki virulensi yang tertinggi dengan mortalitas larva instar II 65\%. Isolat B. bassiana yang virulen terhadap larva C. pavo-nana terdapat pada kelompok genotipe yang sama.
\end{abstract}

Kata kunci: B. bassiana, Crocidolomia pavonana, keragaman, genetik, RAPD, virulensi

\section{PENDAHULUAN}

Crocidolomia pavonana (F.) (Lepidoptera: Pyralidae) merupakan salah satu hama penting pada pertanaman sayuran Brassicaceae seperti kubis, brokoli, kubis bunga, sawi, dan lobak di berbagai daerah di Indonesia dan negeri-

\footnotetext{
*Telp: +6281374289802

Email: trizelia@yahoo.com
}

negeri penghasil kubis lainnya (Kalshoven 1981; Shepard et al. 1997). Serangga ini dikenal juga sebagai hama yang sangat rakus dan secara berkelompok dapat menghabiskan semua daun dan hanya meninggalkan tulang daun saja. Kerusakan yang ditimbulkannya dapat menurunkan hasil sampai $100 \%$. 
Hingga saat ini, pengendalian hama C. pavonana masih sangat tergantung kepada pestisida sintetik, karena cara ini mudah dilaksanakan dan cepat menurunkan populasi hama. Selain itu belum ditemukan alternatif pengendalian lainnya yang cukup efektif. Aplikasi pestisida dilakukan secara intensif, seminggu sekali atau bahkan 2-3 hari sekali (Rauf 1996). Hal ini sangat disayangkan mengingat Indonesia sedang menuju era pembangunan pertanian yang berwawasan lingkungan, sehingga penggunaan pestisida kimia sintetis seharusnya digunakan seminimal mungkin.

Salah satu cara pengendalian hama $C$. pavonana yang ramah lingkungan adalah dengan menggunakan musuh alami serangga hama baik berupa predator, parasitoid maupun patogen. Salah satu jenis patogen serangga yang banyak terdapat di alam dan dapat digunakan untuk pengendalian serangga hama secara hayati adalah cendawan Beauveria bassiana (Balsamo) Vuill. (Deuteromycotina: Hyphomycetes).

Berbagai informasi tentang penggunaan cendawan B. bassiana untuk pengendalian hama telah banyak dilaporkan. Hasil penelitian Trizelia dan Nurdin (2010) menunjukkan bahwa isolat $B$. bassiana yang diisolasi dari hama penggerek buah kopi dapat mematikan hama $C$. pavonana sampai $82,5 \%$. Pada serangga hama ini, infeksi cendawan $B$. bassiana selain dapat menyebabkan kematian larva, juga mempengaruhi konsumsi pakan larva dan biologinya sehingga berpengaruh terhadap perkembangan populasi selanjutnya (Jhonneri 2012).

B. bassiana terdapat di seluruh dunia dan merupakan cendawan entomopatogen yang memiliki jenis inang terbanyak di antara cendawan entomopatogen lain. Inangnya terutama adalah serangga dari ordo Lepidoptera, Coleoptera, Hemiptera, Diptera dan Hymenoptera (Tanada \& Kaya 1993). B. bassiana memiliki strain atau isolat yang kadang-kadang tidak bisa dibedakan secara morfologi dan mempunyai karakter genetik yang berbeda. Adanya keragaman genetik dalam spesies $B$. bassiana ditunjukkan oleh adanya perbedaan patogenisitas (Hajek \& St. Leger 1994). Beretta et al. (1998), mengemukakan bahwa isolat $B$. bassiana yang virulen terhadap Diatraea saccharalis (F.) (Lepidoptera: Pyralidae) memiliki karakter genetik yang berdekatan dan terdapat dalam kelompok genetik yang sama.

Salah satu teknik yang telah digunakan untuk mempelajari keragaman genetik intraspesies B. bassiana. Membedakan isolat atau strain B. bassiana adalah RAPD (Random Amplified Polymorphic DNA) (Maurer et al. 1997; Gaitan et al. 2002; Castrillo et al. 2003; Kaur \& Padmadja 2008). Teknik ini juga dapat digunakan untuk mendeteksi strain yang spesifik, menentukan asal isolat, membedakan strain lokal dengan strain yang diintroduksi (Castrillo et al. 2003), untuk membedakan strain induk dengan strain rekombinan (Dalzoto et al. 2003; Castrillo et al. 2004), dan identifikasi strain atau spesies di dalam dan di antara Beauveria spp. (Glare \&Inwood 1998).

Penelitian ini bertujuan untuk mengetahui keragaman genetik berbagai isolat $B$. bassiana yang diisolasi dari berbagai inang dan geografi di Indonesia dan virulensi cendawan terhadap hama C. pavonana.

\section{BAHAN DAN METODE}

Koleksi dan Perbanyakan Isolat. Isolat $B$. bassiana yang digunakan dalam penelitian ini merupakan koleksi Laboratorium Patologi Serangga Jurusan HPT IPB, Balitro Bogor, koleksi langsung dari serangga yang terinfeksi di lapangan dari lokasi yang berbeda (Tabel 1). Seluruh isolat ditumbuhkan pada medium Sabouraud dextrose agar + yeast extract (SDAY) (dekstrosa $10 \mathrm{~g}$; pepton 2,5 g; ekstrak khamir 2,5 g; agar $20 \mathrm{~g}$; kloramfenicol 0,5 g dan akuades $1 \mathrm{~L}$ ) (Samuels et al. 2002).

Isolasi B. bassiana dari serangga yang telah terinfeksi oleh $B$. bassiana dilakukan dengan cara mengambil miselia

Tabel 1 Sumber isolat B. bassiana yang digunakan untuk studi keragaman genetik

\begin{tabular}{|c|c|c|c|}
\hline Isolat & Asal inang & Stadia & Asal lokasi (Tahun) \\
\hline $\mathrm{Bb}-\mathrm{Nl}$ & Nilaparvata lugens (Stål) (Homoptera: Delphacidae) & Imago & Bogor (2001) \\
\hline Bb-La1 & Leptocorisa oratorius (F.) (Hemiptera: Coreidae) & Imago & Bogor (2001) \\
\hline $\mathrm{Bb}-\mathrm{La} 2$ & Leptocorisa oratorius (F.) (Hemiptera: Coreidae) & Imago & Cianjur (2003) \\
\hline $\mathrm{Bb}-\mathrm{La} 3$ & Leptocorisa oratorius (F.) (Hemiptera: Coreidae) & Imago & Cilacap (2002) \\
\hline $\mathrm{Bb}-\mathrm{La} 4$ & Leptocorisa oratorius (F.) (Hemiptera: Coreidae) & Imago & Probolinggo (2003) \\
\hline $\mathrm{Bb}-\mathrm{Thr}$ & Thrips sp (Thysanoptera: Thripidae) & Imago & Bogor (2002) \\
\hline $\mathrm{Bb}-725$ & Tidak diketahui & - & Bogor (2002) \\
\hline $\mathrm{Bb}-\mathrm{Hh} 1$ & Hypothenemus hampei (Ferr.) (Coleoptera: Scolytidae) & Imago & Bogor (2001) \\
\hline $\mathrm{Bb}-\mathrm{Hh} 2$ & Hypothenemus hampei (Ferr.) (Coleoptera: Scolytidae) & Imago & Fajar Bulan (2002) \\
\hline $\mathrm{Bb}-\mathrm{Cp}$ & Crocidolomia pavonana (F.) (Lepidoptera: Pyralidae) & Larva & Cibodas (2003) \\
\hline $\mathrm{Bb}-\mathrm{Sl}$ & Spodoptera litura (F.) (Lepidoptera: Noctuidae) & Larva & Cibodas (2003) \\
\hline $\mathrm{Bb}-\mathrm{Cc}$ & Chrysodeixis chalcites (Esp.) (Lepidoptera: Noctuidae) & Larva & Ciherang (2002) \\
\hline $\mathrm{Bb}-\mathrm{Rl}$ & Riptortus linearis (L.) (Hemiptera: Alydidae) & Imago & Probolinggo (2003) \\
\hline
\end{tabular}


atau konidianya dan ditumbuhkan pada media SDAY, kemudian dilakukan pemurnian pada media yang sama. Semua isolat diinkubasi pada suhu $25^{\circ} \mathrm{C}$ selama 15 hari. Untuk mempertahankan virulensi isolat yang diuji, semua isolat diinokulasikan kembali pada larva C. pavonana. Dari larva C. pavonana yang terinfeksi diisolasi kembali dan dimurnikan pada media SDAY. Identifikasi dilakukan secara makroskopis dan mikroskopis. Kunci identifikasi yang digunakan adalah kunci Barnett dan Hunter (1972) dan Poinar dan Thomas (1984).

Perbanyakan Miselium untuk Ekstraksi DNA. Konidia dipanen dari biakan cendawan yang telah berumur 15 hari dan dimasukkan ke dalam labu Erlenmeyer yang berisi $100 \mathrm{~mL}$ media cair Sabouraud Dextrose Broth (SDB) (20 g dekstrosa, 10 g pepton, dan 2 g ekstrak khamir) (Goettel \& Inglis 1997), dan diinkubasikan selama 4 hari pada rotary shaker dengan kecepatan $130 \mathrm{rpm}$ dan suhu $25^{\circ} \mathrm{C}$. Miselia dipanen dengan cara disaring menggunakan kertas Whatman No.1 dan dicuci dua kali dengan air suling steril.

Ekstraksi DNA. Ekstraksi DNA dari miselia B. bassiana menggunakan metode yang dikemukakan oleh Hidayat et al. (2002). Miselia cendawan ditimbang sebanyak $1 \mathrm{~g}$, kemudian digerus dalam nitrogen cair dengan menggunakan mortar. Serbuk miselium dipindahkan ke dalam tabung ependorf dan diberi $1500 \mathrm{ml}$ bufer ekstraksi (1,4 M NaCl); $20 \mathrm{mM}$ EDTA (pH 8,0); 100 mM Tris-HCl (pH 8,0); $2 \%$ (w/v) CTAB; 0,2\% b-merkaptoetanol). Campuran dikocok sampai homogen dan dipanaskan dalam penangas air suhu $65^{\circ} \mathrm{C}$ selama 30 menit sambil sesekali digoyang. Kemudian ditambahkan 1 volume campuran fenol : kloroform : isoamil alkohol (25:24:1) dan divorteks. Campuran disentrifugasi pada kecepatan 11.000 rpm selama 15 menit. Fase cair yang terpisah diambil dan dipindahkan ke tabung ependorf baru, kemudian ditambahkan 1 volume campuran kloroform : isoamil alkohol (24:1) dan divorteks. Campuran disentrifugasi pada kecepatan 11.000 rpm selama 15 menit. Supernatan dipindahkan ke tabung ependorf yang baru dan ditambahkan ke dalamnya 1 volume isopropanol dingin dan dikocok perlahan. Larutan diinkubasi pada $-20^{\circ} \mathrm{C}$ selama 30 menit, kemudian disentrifugasi pada 11.000 rpm selama 15 menit. Supernatan yang ada dibuang dan pelet yang didapat dicuci dengan etanol $70 \%$, kemudian disentrifugasi pada $11.000 \mathrm{rpm}$ selama 15 menit. Etanol dibuang dan pelet DNA dikeringkan dengan vakum. Pelet DNA dilarutkan dalam $\mathrm{dH}_{2} \mathrm{O}$ pada suhu ruang lalu disimpan pada suhu $-20^{\circ} \mathrm{C}$.
Amplifikasi DNA dengan Teknik RAPD-PCR. Hasil ekstraksi DNA diamplifikasi dengan teknik RAPD-PCR menggunakan 14 macam primer, yaitu: primer 1-6, OPA5, OPA8, OPA11, OPA13, OPA14, OPA15, OPA17, dan OPB 9. Volume final campuran reaksi PCR adalah $25 \mathrm{~mL}$. Komposisi reaksi PCR sebagai berikut 1 kali PCR buffer $(10 \mathrm{mM} \mathrm{KCl,} 10$ $\mathrm{mM}\left(\mathrm{NH}_{4}\right)_{2} \mathrm{SO}_{4}, 20 \mathrm{mM}$ Tris- $\mathrm{HCl}, 2 \mathrm{mM} \mathrm{MgSO}_{4}, 0,1 \%$ Triton X-100, pH 8,8), 0,2 mM tiap d NTP, 2,5 mM MgCl, $10 \mathrm{mM}$ primer, 2 unit Taq DNA polimerase (New England BioLabs Inc.), $5 \mathrm{~mL}$ DNA sampel dan ditambahkan air sehingga volume mencapai $25 \mathrm{~mL}$. Amplifikasi DNA dengan menggunakan mesin PCR berlangsung dengan urutan sebagai berikut: Tahap 1: pra-amplifikasi PCR selama 2 menit pada suhu $94^{\circ} \mathrm{C}$; Tahap II: amplifikasi PCR dilakukan sebanyak 45 siklus reaksi, dengan pemisahan utas DNA genom (denaturasi) pada suhu $94^{\circ} \mathrm{C}$ selama 1 menit. Penempelan primer (annealing) pada suhu $36^{\circ} \mathrm{C}$ selama 1 menit; sintesis pada suhu $72^{\circ} \mathrm{C}$ selama 2 menit; dan tahap III: Paska amplifikasi pada suhu $72^{\circ} \mathrm{C}$ selama 5 menit.

Analisis DNA pada Agarose gel electrophoresis. Fragmen DNA hasil amplifikasi untuk setiap primer diambil sebanyak $8 \mathrm{~mL}$ dan ditambah dengan $2 \mathrm{~mL}$ larutan penanda (0,25\% Bromophenol Blue dan 40\% (w/v) sukrosa) kemudian dipisahkan dengan elektroforesis pada gel agarosa 1,5\% dengan menggunakan buffer TBE $1 \mathrm{X}$ dan dilanjutkan dengan pewarnaan melalui perendaman gel agarosa dalam larutan etidium bromida $0,5 \mathrm{mg} / \mathrm{mL}$ selama 30 menit dan dibilas dengan $\mathrm{H}_{2} \mathrm{O}$ selama 30 menit. Pita DNA hasil amplifikasi diamati di atas transiluminator UV dan dilanjutkan dengan pemotretan menggunakan alat Gel UV dokumentasi.

Analisis Data Hasil RAPD. Pita polimorfik masing-masing sampel DNA diamati untuk menentukan adanya perbedaan isolat. Setiap posisi pita DNA diubah ke dalam bentuk data biner dengan memberi nilai 1 jika ada pita dan 0 jika tidak ada pita. Data biner ini selanjutnya diolah dengan menggunakan program komputer Numerical Taxonomy and Multivariate Analysis System (NTSys) versi 2.02. Berdasarkan nilai kesamaan genetik tersebut dilakukan analisis pengelompokan (cluster analysis) menggunakan metode Unweight Pair Group Method Average (UPGMA). Hasil analisis pengelompokan tersebut berupa dendogram kesamaan genetik yang menunjukkan hubungan kesamaan antar isolat.

Uji Patogenisitas. Instar larva C. pavonana yang diuji adalah larva instar II yang berumur satu hari. Konsentrasi 
konidia dari masing-masing isolat yang digunakan adalah $10^{8} \mathrm{konidia} / \mathrm{ml}$. Inokulasi cendawan dilaksanakan dengan cara meneteskan $5 \mathrm{~mL}$ suspensi konidia pada bagian dorsal tubuh larva dengan menggunakan alat mikroaplikator. Kemudian larva diberi makan dengan daun kubis segar. Percobaan diulang empat kali dan setiap satuan percobaan terdiri dari 20 ekor larva. Mortalitas larva diamati setiap hari hingga tujuh hari setelah aplikasi $B$. bassiana.

Percobaan disusun dalam rancangan acak lengkap (RAL) dengan 13 taraf perlakuan (jenis isolat). Data hasil percobaan diolah dengan sidik ragam dan dilanjutkan dengan pengujian nilai tengah menggunakan uji Tukey (HSD) pada taraf nyata 5\%.

\section{HASIL DAN PEMBAHASAN \\ Profil Pita RAPD. Hasil seleksi 14 primer terhadap DNA} total 13 isolat $B$. bassiana menunjukkan bahwa hanya primer OPA08 yang menghasilkan pola pita DNA polimorfik yang lebih banyak dan dapat membedakan ketiga belas isolat B. bassiana, sedangkan primer OPA15 dan OPA05 menghasilkan pola pita polimorfik yang lebih sedikit. Perbedaan profil pita DNA hasil amplifikasi dengan menggunakan primer OPA08, OPA15 dan OPA05 dapat dilihat pada Gambar 1. Jumlah dan ukuran pita sangat berperan dalam menentukan tingkat keragaman B. bassiana.

Jumlah pita DNA yang dihasilkan per primer berkisar antara 2-14. Ukuran pita DNA hasil amplifikasi yang diperoleh berkisar antara 490-1900 pasang basa (pb). Hasil penelitian Castrillo et al. (2003), menunjukkan bahwa ukuran pita DNA B. bassiana yang diperoleh berkisar antara 494-1900 pb. Hasil penelitian Kaur dan Padmaja (2008), menunjukkan bahwa ukuran pita DNA B. bassiana yang diperoleh berkisar antara 320-2300 pb. Jumlah pita DNA yang dihasilkan oleh setiap primer tergantung pada banyaknya situs penempelan dari primer yang digunakan pada genom atau sebaran situs pada genom yang homolog dengan sekuen primer. Semakin banyak situs penempelan semakin banyak jumlah pita yang dihasilkan (Motulo 2000; Matondang et al. 2001). Sedikitnya jumlah pita DNA hasil amplifikasi oleh primer OPA15 dan OPA05 menunjukkan sedikitnya jumlah situs pada genom $B$. bassiana yang homolog dengan primer tersebut.

\section{Analisis Keragaman Genetik Isolat-Isolat B. bassiana.} Hasil analisis keragaman genetik dari 13 isolat B. bassiana berdasarkan pada penanda RAPD dengan tiga primer acak (OPA08, OPA15, dan OPA05) ditampilkan dalam bentuk dendogram (Gambar 2). Tiga belas isolat B. bassiana

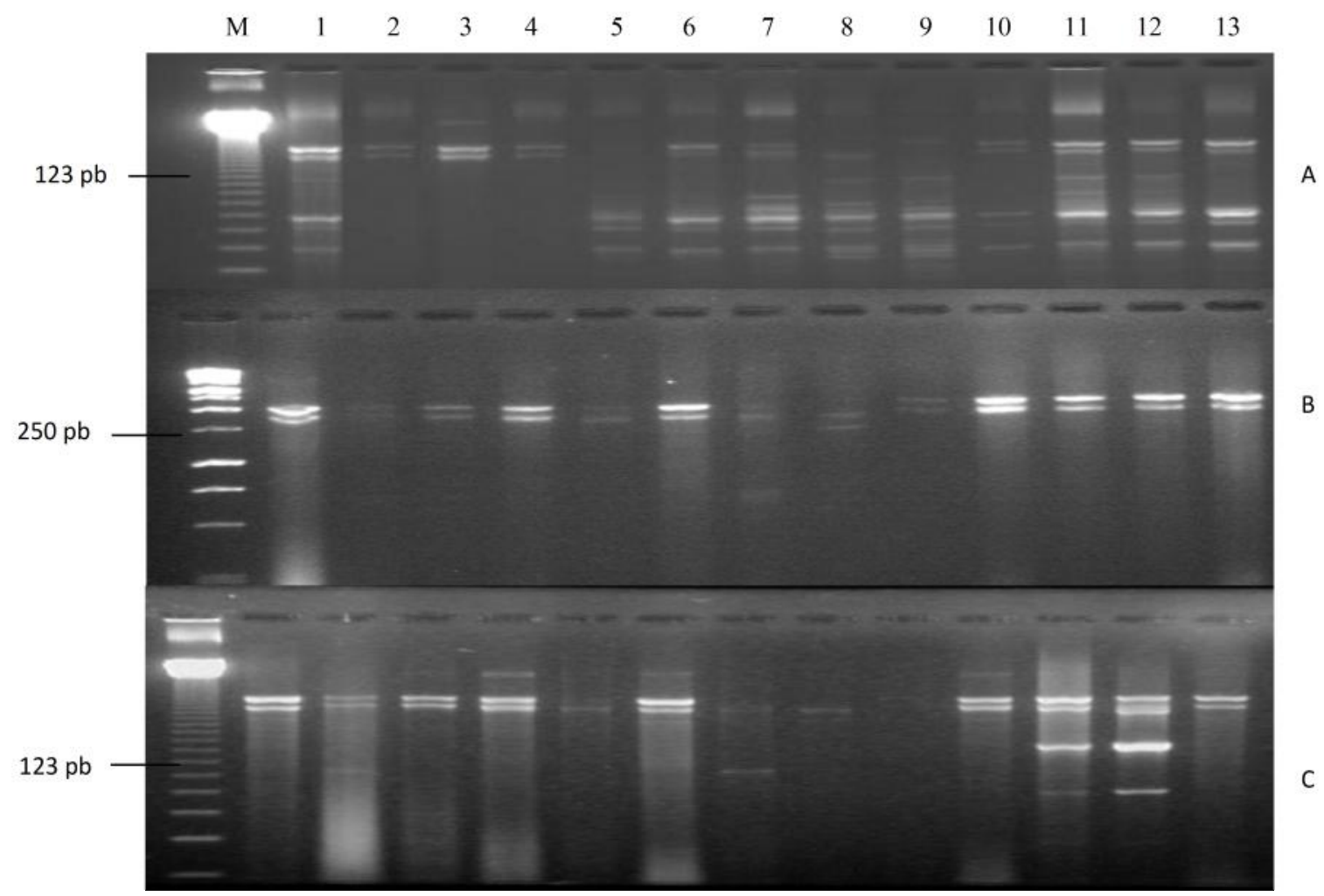

Gambar 1 Profil pita DNA 13 isolat B. bassiana hasil amplifikasi dengan teknik RAPD menggunakan primer: A) OPA08; B) OPA15, dan C) OPA05; M: Marker 123 dan $250 \mathrm{pb}$; 1): isolat Bb-La2; 2): isolat Bb-La3; 3): isolat Bb-La1; 4): isolat Bb-Nl; 5): isolat Bb-Thr; 6): isolat $\mathrm{Bb}-\mathrm{Cc}$; 7): isolat $\mathrm{Bb}-725$; 8): isolat $\mathrm{Bb}-\mathrm{Rl}$; 9): isolat $\mathrm{Bb}-\mathrm{Hh} 1$; 10): isolat $\mathrm{Bb}-\mathrm{Cp} ; 11)$ : $\mathrm{Bb}-\mathrm{Sl}$; 12): isolat $\mathrm{Bb}-\mathrm{Hh} 2$; 13): isolat $\mathrm{Bb}-$ La4. 
membentuk dua kelompok utama dan memisahkan isolat ke dalam 12 genotipe. Hal ini berarti bahwa ada keragaman genetik yang tinggi antar isolat $B$. bassiana. Tingginya keragaman genetik isolat $B$. bassiana karena cendawan ini memiliki inang yang banyak dan tersebar di berbagai daerah dan habitat. Menurut Gaitan et al. (2002), kisaran inang dan kondisi ekologi dapat mempengaruhi keragaman genetik cendawan entomopatogen. Keragaman genetik yang tinggi dari suatu populasi dapat terjadi karena adanya mutasi, rekombinasi gen, reproduksi seksual dan paraseksual, seleksi, heterokariosis dan migrasi gen dari suatu tempat ke tempat lain (McDonald \& McDermott 1993; McDonald 1997). Hasil penelitian yang sama juga dikemukakan oleh Castrillo et al. (2004) yang melaporkan bahwa strain B. bassiana yang diisolasi dari berbagai serangga inang dan dari lokasi yang berbeda di Amerika Utara memiliki keragaman genetik yang tinggi yang ditunjukkan oleh banyaknya terbentuk kelompok genotipe. Dari 34 strain B. bassiana yang diamati, membentuk 32 genotipe yang berbeda.

Pada Gambar 2 terlihat bahwa isolat yang berasal dari inang atau geografi yang sama belum tentu memiliki profil genetik yang sama. Pengelompokan isolat tidak berkaitan dengan sumber inang dan geografi isolat. Menurut Moore dan Landicker (1996) terjadinya keragaman genetik pada cendawan golongan Deuteromycetes disebabkan oleh adanya proses heterokariosis dan siklus paraseksual. Kedua proses ini merupakan sumber keragaman genetik yang utama pada cendawan. Heterokariosis merupakan suatu keadaan dimana pada miselium yang sama terdapat berbagai inti yang berbeda secara genetik dan koloni yang terbentuk dinamakan dengan heterokarion. Adanya heterokariosis ini memberikan peluang bagi cendawan untuk dapat hidup di alam, karena tersedianya sumber daya genetik yang besar untuk dapat beradaptasi pada berbagai kondisi lingkungan. Siklus paraseksual juga bisa terjadi di dalam heterokarion dan melibatkan serangkaian kejadian, yaitu pembentukan heterokarion, diploidisasi dan haploidisasi inti. Melalui siklus paraseksual ini akan menghasilkan strain yang berbeda secara genetik (Moore \& Landicker 1996; Carlile et al. 2001).

Di samping faktor yang ada di dalam cendawan, faktor lain juga dapat mempengaruhi keragaman genetik cendawan entomopatogen. Gaitan et al. (2002), mengemukakan bahwa keragaman genetik cendawan entomopatogen sangat dipengaruhi oleh kisaran inang dan kondisi ekologi. Menurut Bidochka et al. (2000), sifat genetik cendawan entomopatogen dipengaruhi serangga inang dan habitat. Hasil penelitian Gaitan et al. (2002) dan Kaur dan Padmaja (2008), juga menunjukkan bahwa pengelompokan isolat tidak berhubungan dengan sumber inang dan geografi isolat. Akan tetapi hasil penelitian Maurer et al. (1997), menunjukkan bahwa pengelompokan isolat $B$. bassiana berkaitan dengan sumber inang dan tidak berkaitan dengan sumber geografi isolat. Serangga inang merupakan faktor yang sangat berperan dalam menentukan struktur populasi B. bassiana.

Pada dendogram juga terlihat bahwa isolat Bb-La1 dan Bb-Nl mempunyai kesamaan genetik 100\%. Hal ini berarti bahwa kedua isolat ini memiliki karakter genetik yang sama. Kesamaan genetik ini mungkin disebabkan karena kedua isolat ini berasal dari daerah yang sama, yaitu dari Bogor.

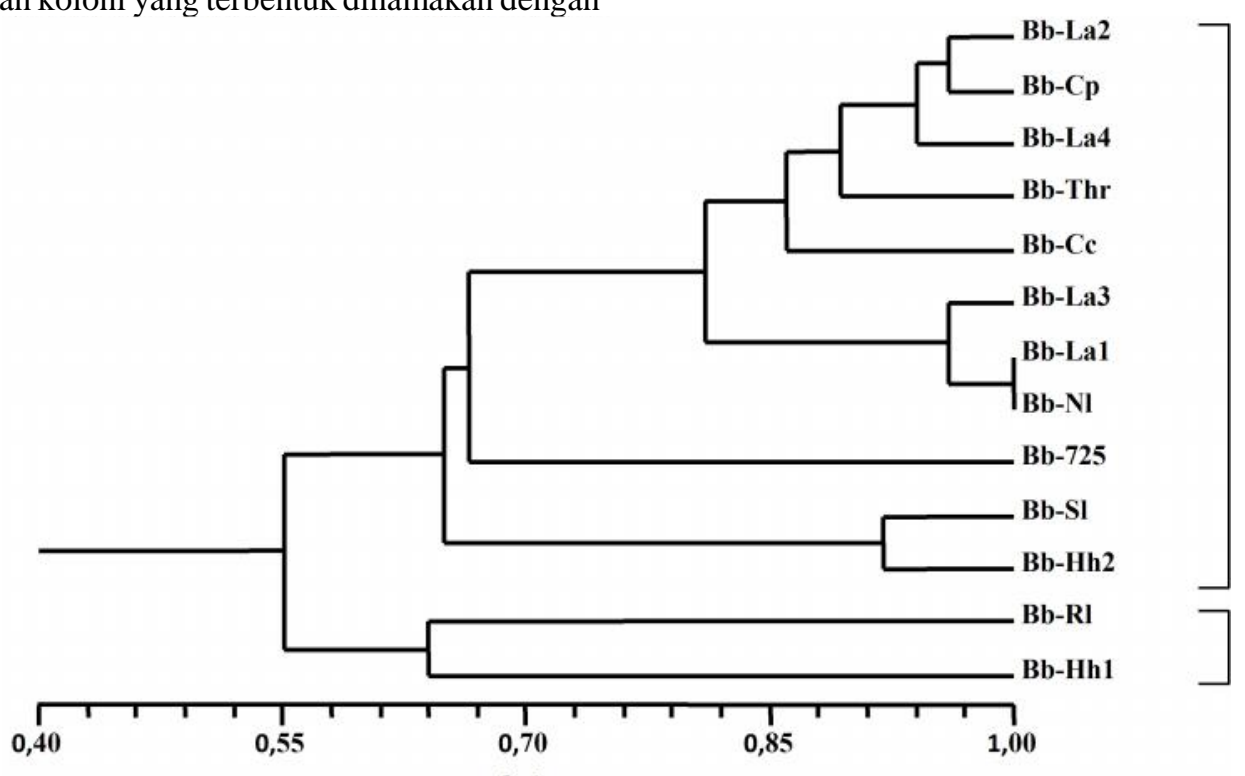

Koefisien

Gambar 2 Dendogram kesamaan genetik 13 isolat B. bassiana dengan menggunakan 3 primer (OPA08, OPA15, dan OPA05) 
Di samping itu asal inang kedua isolat yaitu $N$. lugens dan L. oratorius sama-sama hama utama tanaman padi dan berada pada habitat yang sama, sehingga memungkinkan untuk terjadinya rekombinasi genetik. Faktor habitat diduga juga berpengaruh terhadap genotipe cendawan. Menurut Bidochka et al. (2000), habitat dapat mempengaruhi persebaran dan kelimpahan spesies serangga dan juga mempengaruhi persebaran genotipe cendawan. Seleksi habitat memegang peranan penting dalam genetik populasi cendawan dan habitat dapat mempengaruhi struktur genetik populasi, sehingga mengakibatkan tingginya keragaman genetik cendawan entomopatogen.

Uji Patogenisitas. Hasil penelitian menunjukkan bahwa isolat $B$. bassiana yang berasal dari geografi dan inang yang berbeda mempunyai virulensi yang berbeda nyata terhadap larva $C$. pavonana instar II. Isolat Bb-La2 merupakan isolat yang paling virulen dengan rata-rata mortalitas larva C. pavonana tertinggi yaitu $65,00 \%$ pada pengamatan hari ketujuh setelah aplikasi konidia. Isolat $\mathrm{Bb}-\mathrm{Cp}$ juga memiliki virulensi yang tinggi dengan mortalitas larva 61,25\%. Isolat $\mathrm{Bb}-\mathrm{Hh} 1$ merupakan isolat yang mempunyai kategori virulensi sangat rendah dengan mortalitas 42,50\% (Tabel 2).

Adanya perbedaan virulensi dari 13 isolat $B$. bassiana yang diuji didasari oleh adanya perbedaan karakter genetik dan fisiologi antar isolat. Sifat genetik dan fisiologi B. bassiana mempunyai peranan penting dalam patogenisitas atau virulensi cendawan terhadap serangga hama dan persistensi cendawan di lingkungan yang selanjutnya mempengaruhi keberhasilan (efikasi) pengendalian. Menurut Bidochka et al. (2000), ada beberapa kelompok gen yang terlibat dalam proses infeksi atau patogenisitas, yaitu: a) gen yang terlibat dalam mendeteksi adanya inang sehingga menyebabkan terjadinya proses perkecambahan dan differensiasi; b) gen yang mengkode pembentukan berbagai jenis enzim yang berfungsi untuk menghancurkan kutikula seperti Pr1, kitinase; dan c) gen yang mengkode pembentukan senyawa peptida yang berperan dalam mengganggu sistem pertahanan serangga. Adanya peranan genetik cendawan ini dalam proses infeksi dan mempengaruhi virulensi cendawan terhadap serangga terlihat dari hasil penelitian yang menunjukkan bahwa perbedaan karakter genetik antar isolat B. bassiana sejalan dengan perbedaan patogenisitas.

Berdasarkan hasil analisis keragaman genetik dari isolat B. bassiana berdasarkan pada penanda RAPD dengan tiga primer acak (OPA08, OPA15, dan OPA05) yang ditampilkan dalam bentuk dendogram menunjukkan bahwa untuk isolat B. bassiana yang virulen terhadap C. pavonana (isolat $\mathrm{Bb}-\mathrm{La} 2$ dan $\mathrm{Bb}-\mathrm{Cp}$ ) memiliki kesamaan genetik yang tinggi yaitu $95 \%$ dan terdapat dalam kelompok genetik yang sama.

Hasil penelitian Beretta et al. (1998) menujukkan bahwa isolat B. bassiana yang virulen terhadap Diatraea saccharalis (F.) (Lepidoptera: Pyralidae) memiliki karakter genetik yang berdekatan dan terdapat dalam kelompok genetik yang sama.

\section{SIMPULAN}

Hasil seleksi 14 primer menunjukkan bahwa hanya primer OPA08 yang menghasilkan pola pita DNA polimorfik yang lebih banyak sedangkan primer lain menghasilkan pita polimorfik yang lebih sedikit. Hasil analisis keragaman genetik isolat-isolat B. bassiana dengan teknik RAPD-PCR

Tabel 2 Mortalitas larva C. pavonana instar II setelah aplikasi 13 isolat B. bassiana pada konsentrasi $10^{8} \mathrm{konidia} / \mathrm{ml}$

\begin{tabular}{|c|c|c|c|c|c|c|c|}
\hline \multirow[t]{3}{*}{ Isolat } & \multicolumn{7}{|c|}{ Rata-rata mortalitas larva (\%) } \\
\hline & \multicolumn{7}{|c|}{ Hari ke- } \\
\hline & 1 & 2 & 3 & 4 & 5 & 6 & 7 \\
\hline $\mathrm{Bb}-\mathrm{La} 2$ & $1,25 \mathrm{a}$ & $7,50 \mathrm{a}$ & $16,25 \mathrm{ab}$ & $26,25 \mathrm{ab}$ & $40,00 \mathrm{ab}$ & $52,50 \mathrm{ab}$ & $65,00 \mathrm{a}$ \\
\hline $\mathrm{Bb}-\mathrm{Cp}$ & $0,00 \mathrm{a}$ & $6,25 \mathrm{a}$ & $16,25 \mathrm{ab}$ & $33,75 \mathrm{a}$ & $42,50 \mathrm{a}$ & $56,25 \mathrm{a}$ & $61,25 \mathrm{ab}$ \\
\hline $\mathrm{Bb}-\mathrm{Thr}$ & $0,00 \mathrm{a}$ & $2,50 \mathrm{a}$ & $17,50 \mathrm{ab}$ & $33,75 \mathrm{a}$ & $45,00 \mathrm{a}$ & $52,50 \mathrm{ab}$ & $58,75 \mathrm{abc}$ \\
\hline $\mathrm{Bb}-\mathrm{S} 1$ & $0,00 \mathrm{a}$ & $3,75 \mathrm{a}$ & $16,25 \mathrm{ab}$ & $31,25 \mathrm{ab}$ & $37,50 \mathrm{ab}$ & $45,00 \mathrm{abc}$ & $57,50 \mathrm{abc}$ \\
\hline $\mathrm{Bb}-\mathrm{Hh} 2$ & $0,00 \mathrm{a}$ & $8,75 \mathrm{a}$ & $20,00 \mathrm{ab}$ & $32,50 \mathrm{ab}$ & $38,75 \mathrm{ab}$ & $47,50 \mathrm{abc}$ & $53,75 \mathrm{abc}$ \\
\hline Bb-La3 & $0,00 \mathrm{a}$ & $1,25 \mathrm{a}$ & $7,50 \mathrm{bc}$ & $13,75 \mathrm{abc}$ & $25,00 \mathrm{ab}$ & $41,25 \mathrm{abc}$ & $47,50 \mathrm{bc}$ \\
\hline $\mathrm{Bb}-725$ & $0,00 \mathrm{a}$ & $5,00 \mathrm{a}$ & $6,25 \mathrm{bc}$ & $21,25 \mathrm{abc}$ & $30,00 \mathrm{ab}$ & $37,50 \mathrm{abc}$ & $45,00 \mathrm{bc}$ \\
\hline Bb-La4 & $0,00 \mathrm{a}$ & $2,50 \mathrm{a}$ & $5,00 \mathrm{bc}$ & 8,75 bc & $18,75 \mathrm{bc}$ & $32,50 \mathrm{c}$ & $45,00 \mathrm{bc}$ \\
\hline $\mathrm{Bb}-\mathrm{Nl}$ & $0,00 \mathrm{a}$ & $8,75 \mathrm{a}$ & $23,75 \mathrm{a}$ & $30,00 \mathrm{ab}$ & $35,00 \mathrm{ab}$ & $40,00 \mathrm{abc}$ & $45,00 \mathrm{bc}$ \\
\hline $\mathrm{Bb}-\mathrm{R} 1$ & $0,00 \mathrm{a}$ & $0,00 \mathrm{a}$ & $6,25 \mathrm{bc}$ & $17,50 \mathrm{abc}$ & $26,25 \mathrm{ab}$ & $35,00 \mathrm{bc}$ & $43,75 \mathrm{c}$ \\
\hline BB-La1 & $0,00 \mathrm{a}$ & $3,75 \mathrm{a}$ & $13,75 \mathrm{abc}$ & $20,00 \mathrm{abc}$ & $28,75 \mathrm{ab}$ & $35,00 \mathrm{bc}$ & $43,75 \mathrm{c}$ \\
\hline $\mathrm{Bb}-\mathrm{Cc}$ & $0,00 \mathrm{a}$ & $5,00 \mathrm{a}$ & $17,50 \mathrm{ab}$ & $22,25 \mathrm{abc}$ & $27,50 \mathrm{ab}$ & $35,00 \mathrm{bc}$ & $43,75 \mathrm{c}$ \\
\hline $\mathrm{Bb}-\mathrm{Hh} 1$ & $0,00 \mathrm{a}$ & $5,00 \mathrm{a}$ & $5,00 \mathrm{bc}$ & $23,75 a b c$ & $28,75 \mathrm{ab}$ & $38,75 \mathrm{abc}$ & $42,50 \mathrm{c}$ \\
\hline Kontrol & $0,00 \mathrm{a}$ & $0,00 \mathrm{a}$ & $0,00 \mathrm{c}$ & $0,00 \mathrm{c}$ & $0,00 \mathrm{c}$ & $1,25 \mathrm{~d}$ & $2,50 \mathrm{~d}$ \\
\hline Nilai F & 1,00 & 1,50 & 5,55 & 4,41 & 7,21 & 11,40 & 20,43 \\
\hline Nilai P & 0,4684 & 0,1595 & 0,0001 & 0,0001 & 0,0001 & 0,0001 & 0,0001 \\
\hline
\end{tabular}

Angka yang diikuti huruf yang sama pada kolom yang sama tidak berbeda nyata menurut uji Tukey (HSD) pada taraf nyata 5\% 
menunjukkan bahwa 13 isolat $B$. bassiana membentuk dua kelompok isolat dan memisahkan isolat ke dalam 12 genotipe. Pengelompokan isolat tidak berhubungan dengan asal inang dan geografi isolat.

Hasil uji patogenisitas menunjukkan bahwa isolat $\mathrm{Bb}-\mathrm{La} 2$ dan $\mathrm{Bb}-\mathrm{Cp}$ memiliki virulensi yang tinggi, menghasilkan mortalitas larva $C$. pavonana berkisar antara 61,25-65\%. Isolat $B$. bassiana yang virulen terhadap C. pavonana yaitu isolat $\mathrm{Bb}-\mathrm{La} 2$ dan $\mathrm{Bb}-\mathrm{Cp}$ memiliki kesamaan genetik yang tinggi yaitu 95\% dan terdapat dalam kelompok genetik yang sama.

\section{DAFTAR PUSTAKA}

Barnett, H.L \& Hunter, B.B. 1972. Illustrated Genera of Imperfect Fungi. $3^{\text {rd }}$ Ed. Minneapolis: Burges Publishing Company.

Berretta, M.F., Lecuona, R.E., Zandomeni, R.O \& Grau O. 1998. Genotyping isolates of the entomopathogenic fungus Beauveria bassiana by RAPD with fluorescent labels. J Invertebr Pathol 71: 145-150.

Bidochka, M.J., Kamp. A.M \& de Croos, J.N.A. 2000. Insect Pathogenic Fungi: from Genes to Populations. Di dalam: Kronstad JW, editor. Fungal Pathology. Netherlands: Kluwer Academic Publishers.

Bielikova, L., Landa, Z., Osborne, L.S \& Curn, V.2002. Characterization and identification of the entomopathogenic and mycoparasitic fungi using RAPD-PCR technique. Plt Prot Sci 38(1): 1-12.

Carlile, M.J., Watkinson, S.C \& Gooday, G.W. 2001. The Fungi. $2^{\text {nd }}$ ed. San Diego: Academic Press.

Castrillo, L.A., Griggs. M.H \& Vandenberg, J.D. 2004. Vegetative compatibility groups in indigenous and massreleased strains of the entomopathogenic fungus Beauveria bassiana: likelihood of recombination in the field. J Invertebr Pathol 86: 26-37.

Castrillo, L.A., Vandenberg, J.D \& Wraight S.P. 2003. Strainspecific detection of introduced Beauveria bassiana in agricultural fields by use of sequence-characterized amplified region markers. J Invertebr Pathol 82: 75-83.

Castrillo, L.A., Wiegmann, B.M \& Brooks, W.M. 1999. Genetic variation in Beauveria bassiana populations associated with the darkling beetle, Alphitobius diaperinus. J Invertebr Pathol 73: 269-275.

Dalzoto, P.R., Glienke-Blanco, C., Kava-Cordeiro, V., Araujo, W.L \& Azevedo, J.L. 2003. RAPD analyses of recombination processes in the entomopathogenic fungus Beauveria bassiana. Mycol Res 107(9): 1069-1074.

Gaitan, A., Valderrama, A.M., Saldarriaga, G., Velez, P \& Bustillo, A. 2002. Genetic variability of Beauveria bassiana associated with the coffe berry borer Hypothenemus hampei and other insects. Mycol Res 106(1): 1307-1314.
Glare, T.R \& Inwood, A.J. 1998. Morphological and genetic characterization of Beauveria spp. from New Zealand. Mycol Res 102(2): 250-256.

Goettel, M.S \& Inglis, G.D. 1997. Fungi: Hyphomycetes. Di dalam Lacey, LA. Editor. Biological techniques, Manual of Techniques in Insect Pathology. San Diego: Academic Press.

Hajek, A.E \& St. Leger, R.J. 1994. Interactions between fungal pathogens and insect hosts. Annu Rev Entomol 39: 293-322.

Hidayat, S.H., Hidayat, P \& Suastika, G. 2002. Penuntun Praktikum Matakuliah Aplikasi Teknik Biologi Molekul untuk Fitopatologi dan Entomologi. Bogor: Jurusan Hama dan Penyakit Tumbuhan Faperta IPB.

Jhonneri. 2012. Pengaruh konsentrasi konidia cendawan entomopatogen Beauveria bassiana (Bals.) Vuill. terhadap laju konsumsi dan biologi hama Crocidolomia pavonana F. (Lepidoptera:Pyralidae). Skripsi. Padang: Fakultas Pertanian Universitas Andalas.

Kalshoven, L.G.E. 1981. The pest of crops in Indonesia. Lann PA van der, penerjemah. Jakarta: Ichtiar Baru-Van Hoeve. Terjemahan dari: De Plagen van de Cultuurgewassen in Indonesie.

Kaur, G \& Padmaja, V. 2008. Evaluation Beauveria bassiana isolates for virulence against Spodoptera litura (Fab.) (Lepidoptera:Noctuidae) and their characterization by RAPD-PCR. Afr J Microbiol Res 2: 299-307.

Lengkong, E.F., Suharsono., Runtunuwu, S.D \& Hartana, A. 2001. Pengoptimuman reaksi berantai polimerase DNA tanaman kelapa. Hayati 8(4): 121-123.

Matondang, I., Suharsono \& Hartana A. 2001. Analisis keanekaragaman genetik kelapa dalam asal Maluku menggunakan teknik Random Amplified Polymorphic DNA. Hayati 8(2): 31-34.

Maurer, P., Couteaudier, Y., Girard, P.A., Bridge, P.D \& Riba G. 1997. Genetic diversity of Beauveria bassiana and relatedness to host insect range. Mycol Res 101(2): 159-164.

McDonald, B.M \& McDermott, J.M. 1993. Population genetic of plant pathogenic fungi, electrophoretic markers given unprecedented precision to analysis of genetic structure of population. Bio Science 43: 311-319.

McDonald BA. 1997. The population genetics of fungi: tools and techniques. Phytopathology 87: 448-453.

Michael, J., Bidochka, Andrena, M., Kamp, T., Michael Lavender, Jason Dekoning \& Amritha De Croos, J. N. 2001. Habitat association in two genetic groups of the insectpathogenic fungus Metarhizium anisopliae: uncovering cryptic species?. Appl Environ Microbiol 67(3): 1335-1342.

Moore, E \& Landicker. 1996. Fundamentals of the Fungi. $4^{\text {th }}$ Ed. New Jersey: Prentice Hall.

Motulo, H.F.J. 2000. Keragaman genetik beberapa isolat Phytophthora palmivora penyebab penyakit gugur buah kelapa berdasarkan penanda Random Amplified 
Polymorphic DNA (RAPD). Tesis. Bogor: Program Pascasarjana IPB.

Poinar, Jr.G.O \& Thomas, G.M. 1984. Laboratory Guide to Insect Pathogens and Parasites. New York: Plenum Press.

Rauf, A. 1996. PHT mereguk manfaat dari globalisasi pasar. Makalah disajikan pada Seminar dan Rapat Koordinasi Wilayah II, Himpunan Mahasiswa Perlindungan Tanaman Indonesia Bogor, Bogor, 22-24 Desember 1996.

Samuels, R.I., Coracini, D.L.A., dos Santos, .C.A.M \& Gava, C.A.T. 2002. Infection of Blissus antillus (Hemiptera: Lygaeidae) eggs by entomopathogenic fungi Metarhizium anisopliae and Beauveria bassiana. Biol Contr 23: 269-273.
Shepard, M., Shepard, E.F., Carner, G.R., Hamming, M.D., Rauf, A., Turnipseed, S.G \& Samsudin. 1997. Prospect for IPM in secondary food crops. Makalah disajikan pada Kongres V dan Simposium Entomologi, Perhimpunan Entomologi Indonesia, Bandung, 24-26 Juni 1997.

Tanada, Y \& Kaya, H.K. 1993. Insect Pathology. New York: San Diego Academic Press, INC. Harcourt Brace Jovanovich, Publisher.

Trizelia \& Nurdin, F. 2010. Virulence of entomopathogenic fungus Beauveria bassiana isolates to Crocidolomia pavonana f (lepidoptera: crambidae). Agrivita 32(3): 254-260. 